\title{
Assessment of Metal Pollution in the Sediments of Ras Al-Ardh and Yacht Club Marinas, Kuwait
}

\author{
Amr A. El-Sammak ${ }^{1 *}$ (i) , Amal F. Alotaibi ${ }^{2}$ \\ ${ }^{1}$ Department of Oceanography, Faculty of Science, Alexandria University, Alexandria, Egypt \\ ${ }^{2}$ Department of Environmental Health, Public Authority for Applied Education and Training, College of Health Sciences, Kuwait \\ E-mail: elsammakamr@yahoo.com
}

Received: 24 March 2021; Revised: 20 May 2021; Accepted: 23 June 2021

\begin{abstract}
This study aims to investigate the fate and behavior of five trace metals $(\mathrm{Fe}, \mathrm{Ni}, \mathrm{Pb}, \mathrm{Cu}$ and $\mathrm{V})$ in the surface sediments of two selected marinas, namely Ras Al-Ardh and Yacht Club, along the coastal area of Kuwait. Leached and total concentrations of $\mathrm{Fe}, \mathrm{Ni}, \mathrm{Pb}, \mathrm{Cu}$ and $\mathrm{V}$ were measured along with the total organic carbon (TOC) and sediment grain size. The bioavailability of the trace metals was also determined using simple extraction techniques. The contamination factor (CF), enrichment factor (EF) and pollution load index (PLI) were used for assessing sediment quality at the marinas. The results indicated that TOC was related to the mean grain size, where higher TOC concentrations were associated with finer grain fractions. Trace metal distribution patterns were similar to the TOC in the sediments. The value of PLI showed that the Ras Al-Ardh marina had higher metal enrichment than that of the Yacht Club marina. The results of CF and EF indicated that the sediments within both marinas are "slightly polluted" to "moderately polluted". The sediments were less contaminated with $\mathrm{Cu}$ relative to $\mathrm{Pb}$ and $\mathrm{Ni}$. The PLI class of metals at the Yacht Club indicated that the marina can be classified as "non-polluted" to "moderately polluted", while the Ras Al-Ardh marina can be classified as "moderately polluted" to "polluted". The study revealed that sediment grain size, TOC, and trace metal concentrations varied spatially within each marina depending on the type of development and the probable source of metals. Sediment quality has changed tremendously due to the expansion of tourism, progress in industrial activities and increase in recreational requirements near the coastal areas.
\end{abstract}

Keywords: marinas, pollution load index, sediment particle size, total organic carbon, trace metals

\section{Introduction}

A marina, which is a touristic port for entertaining vessels, is the terrestrial and marine space that serves as an entertaining vessel for long-term anchoring, transient terrestrial deposit or service of passing vessels. Marinas are areas of special concern because of the potential for pollutant accumulation within their protected waters. Kuwait's coastal area plays a very important role in the development of the country because most of the urban, commercial, industrial and recreational activities are concentrated along the shoreline [1]. The whole southern coastal area of Kuwait is almost completely urbanized by ports and marinas [2]. Some of these marinas are comprised mainly of one entrance (inlet/ outlet). Improper design and maintenance of these marinas resulted in high pollution level in the ecosystem. In the 1960s and 1970s, there was an increase in boating activities in Kuwait and many marinas were developed. Unlike earlier

Copyright (C2021 Amr A. El-Sammak, et al.

DOI: https://doi.org/10.37256/epr.112021838

This is an open-access article distributed under a CC BY license

(Creative Commons Attribution 4.0 International License)

https://creativecommons.org/licenses/by/4.0/ 
marinas from the 1960s, which were designed with single narrow entrances, recent marinas generally incorporate dual entrances or include a second flushing channel to promote water circulation [3].

The determination of the chemical forms of heavy metals in marine sediments with respect to their ability to cross biological membranes (bioavailability) is becoming increasingly important [4,5]. Bioavailability can be defined as the fraction of the total contaminants in industrial water and the sediment particles that are available for bioaccumulation [6].

Metal contamination in the seawater along the coastline has been reported since early 1998 [7]. Subsequent studies of metals in the seawater along the Kuwait Bay and coastline reflected elevated levels of metals including $\mathrm{Cu}, \mathrm{Fe}, \mathrm{Zn}$, $\mathrm{Pb}, \mathrm{Ni}$, and $\mathrm{Co}[8,9]$. The present study aims at investigating the fate and behavior of trace metals, namely $\mathrm{Pb}, \mathrm{Cu}, \mathrm{Ni}$, $\mathrm{V}$ and $\mathrm{Cd}$ in the surface sediments of the two selected marinas along the coastal area of Kuwait (Figure 1). The specific objectives of the study are to determine the partition patterns of some environmentally important trace metals in the sediments of the marinas and to evaluate the pollution load in terms of the degree of contamination (concentration) of the studied metals.
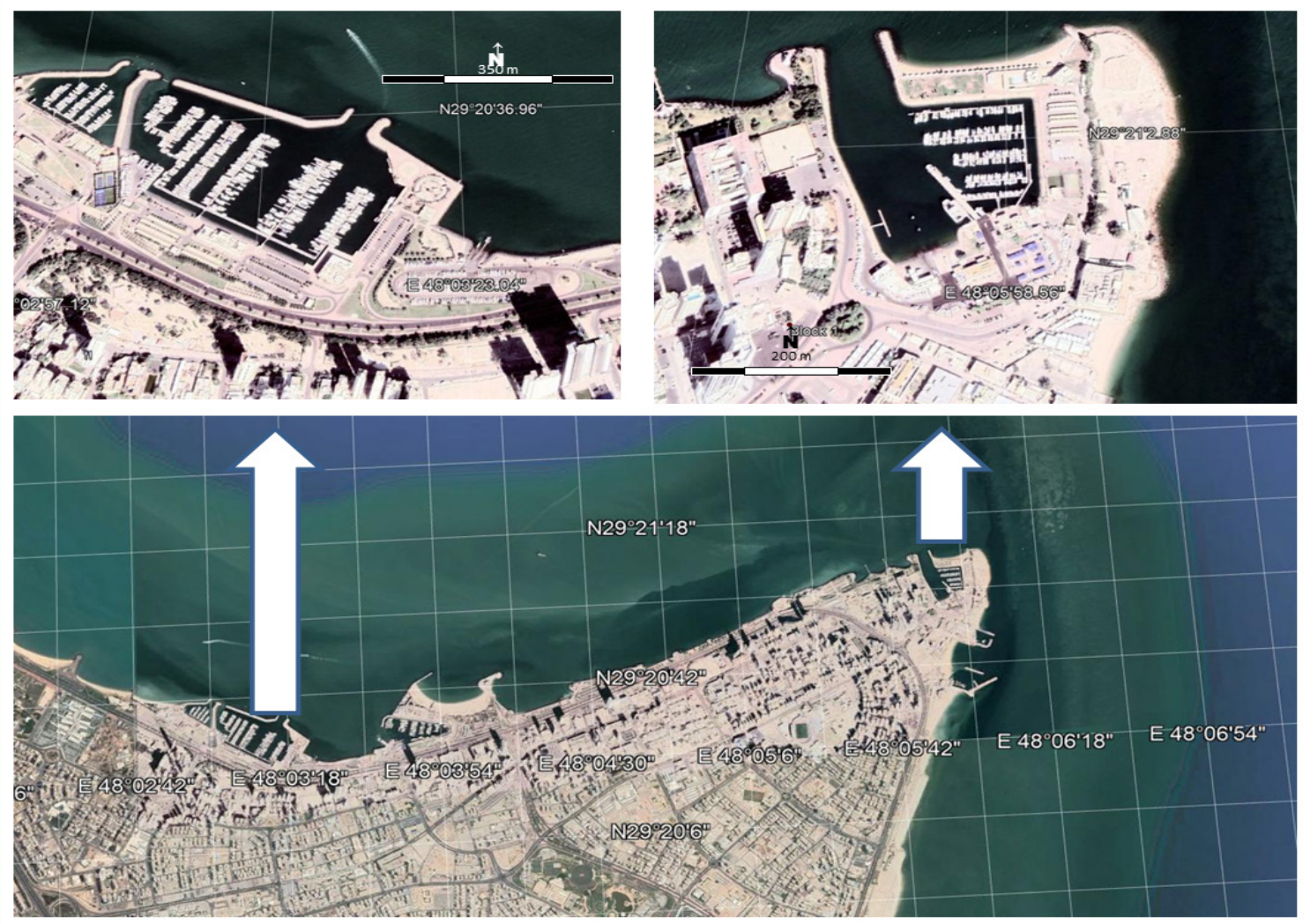

Figure 1. Locations of Ras Al-Ardh (upper right corner) and Yacht Club marinas (upper left corner)

\section{Materials and methods}

Two marinas were selected, both of which are located in the southeastern part of Kuwait Bay. These marinas are Ras Al-Ardh and the Yacht Club. The Yacht Club marina is larger than Ras Al-Ardh and is thought to be more occupied and polluted. The Yacht Club is a major yacht and boat anchorage club in the region. It is located at $29^{\circ} 20^{\prime} \mathrm{N}, 48^{\circ} 03^{\prime} \mathrm{E}$. It was first opened in February 1988. The Yacht Club has a total area of 2,250 $\mathrm{m}^{2}$ consisting of a $120,000 \mathrm{~m}^{2}$ anchorage facility with a capacity of 390 boats of different sizes, each not less than 25 feet. It also has a specialized maintenance and repair workshop offering comprehensive services. There is also gas station, reception hall, games hall, conference hall, marine survey center and public slipway. The Yacht Club has been used for special activities such as annual boat 
and marine equipment exhibitions and speed boat championships. There is also a helicopter pad at the marina. This marina has two openings, one is the entrance and the second one is for promoting water circulation.

The Ras Al-Ardh Club marina has a total geographical area of $9,025 \mathrm{~m}^{2}$ and is located in the Ras Al-Salmiya district, which is considered as one of the best touristic areas in Kuwait. It was established in the 1970s and was expanded in 2000. Its geographical location is $29^{\circ} 21^{\prime} \mathrm{N}, 48^{\circ} 05^{\prime} \mathrm{E}$. Ras Al-Ardh Club offers diversified entertaining services such as play gardens, large multi-use hall, volleyball, basketball and tennis courts, walking track and two swimming pools.

20 sediment samples were collected from the two marinas. Surface sediment samples were collected using the Van Veen grab sampler. 12 samples were collected from Ras-Al-Ardh, while eight samples were collected from the Yacht Club (Table 1, Figure 1). The sampling area covered the entrance, outlet, and boat areas, of each marina. During sampling, water parameters such as $\mathrm{pH}$, dissolved oxygen (DO), and temperature were measured at three different depths, i.e., surface, middle and bottom layers, using a multi-parameter probe (Model YSI6600).

Table 1. Coordinates of the sampling sites

\begin{tabular}{|c|c|c|c|}
\hline Marina & Sample No & Latitude (North) & Longitude (East) \\
\hline \multirow[t]{12}{*}{ Ras Al-Ardh } & R1 & $29^{\circ} 21^{\prime} 1.76^{\prime \prime}$ & $48^{\circ} 5^{\prime} 54.71^{\prime \prime}$ \\
\hline & $\mathrm{R} 2$ & $29^{\circ} 21^{\prime} 4.22^{\prime \prime}$ & $48^{\circ} 5^{\prime} 53.49^{\prime \prime}$ \\
\hline & $\mathrm{R} 3$ & $29^{\circ} 21^{\prime} 0.48^{\prime \prime}$ & $48^{\circ} 5^{\prime} 59.89^{\prime \prime}$ \\
\hline & R4 & $29^{\circ} 21^{\prime} 2.52^{\prime \prime}$ & $48^{\circ} 5^{\prime} 55.98^{\prime \prime}$ \\
\hline & R5 & $29^{\circ} 21^{\prime} 0.30^{\prime \prime}$ & $48^{\circ} 5^{\prime} 56.90^{\prime \prime}$ \\
\hline & R6 & $29^{\circ} 21^{\prime} 2.69^{\prime \prime}$ & $48^{\circ} 5^{\prime} 59.70^{\prime \prime}$ \\
\hline & R7 & $29^{\circ} 21^{\prime} 3.95^{\prime \prime}$ & $48^{\circ} 5^{\prime} 564.19^{\prime \prime}$ \\
\hline & R8 & $29^{\circ} 21^{\prime} 6.47^{\prime \prime}$ & $48^{\circ} 5^{\prime} 52.35^{\prime \prime}$ \\
\hline & R9 & $29^{\circ} 20^{\prime} 58.50^{\prime \prime}$ & $48^{\circ} 5^{\prime} 56.09^{\prime \prime}$ \\
\hline & $\mathrm{R} 10$ & $29^{\circ} 21^{\prime} 2.60^{\prime \prime}$ & $48^{\circ} 5^{\prime} 59.06^{\prime \prime}$ \\
\hline & $\mathrm{R} 11$ & $29^{\circ} 21^{\prime} 4.06^{\prime \prime}$ & $48^{\circ} 5^{\prime} 58.24^{\prime \prime}$ \\
\hline & R12 & $29^{\circ} 21^{\prime} 1.31^{\prime \prime}$ & $48^{\circ} 5^{\prime} 56.56^{\prime \prime}$ \\
\hline \multirow[t]{8}{*}{ Yacht Club } & Y1 & $29^{\circ} 20^{\prime} 40.0^{\prime \prime}$ & $48^{\circ} 3^{\prime} 3.02^{\prime \prime}$ \\
\hline & Y2 & $29^{\circ} 20^{\prime} 30.02^{\prime \prime}$ & $48^{\circ} 3^{\prime} 9.69^{\prime \prime}$ \\
\hline & Y3 & $29^{\circ} 20^{\prime} 33.69^{\prime \prime}$ & $48^{\circ} 3^{\prime} 12.34^{\prime \prime}$ \\
\hline & Y4 & $29^{\circ} 20^{\prime} 35.15^{\prime \prime}$ & $48^{\circ} 3^{\prime} 16.29^{\prime \prime}$ \\
\hline & Y5 & $29^{\circ} 20^{\prime} 31.94 "$ & $48^{\circ} 3^{\prime} 6.58^{\prime \prime}$ \\
\hline & Y6 & $29^{\circ} 20^{\prime} 35.45^{\prime \prime}$ & $48^{\circ} 3^{\prime} 8.96^{\prime \prime}$ \\
\hline & Y7 & $29^{\circ} 20^{\prime} 34.55^{\prime \prime}$ & $48^{\circ} 3^{\prime} 3.01^{\prime \prime}$ \\
\hline & Y8 & $29^{\circ} 20^{\prime} 40.00^{\prime \prime}$ & $48^{\circ} 3^{\prime} 3.03^{\prime \prime}$ \\
\hline
\end{tabular}

The total and leachable (bioavailable) parts of $\mathrm{Fe}, \mathrm{Ni}, \mathrm{Pb}, \mathrm{Cu}$ and $\mathrm{V}$ were analyzed according to the method described in a previous study [10]. Acetic acid was used to remove the leachable portions of the studied metals. The residual fractions were extracted using concentrated hydrofluoric acid. The total metal concentrations are equal to the sum of residual and leachable fractions [11]. Atomic Absorption Spectrophotometry (SHIMADZU AAS-7000) was used for the determination of metal concentrations. The method described by the Manual of Oceanographic Observation and Pollutant Analyses Methods (MOOPAM) [12], was used for the determination of total organic carbon (TOC) and sediment grain size parameters (mean grain size and sorting)

In the present study, the contamination factor (CF), pollution load index (PLI) and enrichment factor (EF) were used in order to assess the level of metal pollution. EF is commonly used to distinguish metals originating from anthropogenic and natural sources. For data normalization purposes, the sample metal concentrations were initially normalized to reference elements (e.g., Fe or Al) to determine whether a sediment sample is enriched with metals in comparison to the sample's background conditions. To determine EF values (Equation 1), $\mathrm{Fe}$ is commonly selected as a normalizing element because it is a major sorbent phase for trace metals [13]. According to this, EF is the ratio between metal $(x)$ divided by the measured Fe concentration for each sample and the background metal/Fe concentration ratio as follows: 


$$
E F=\frac{\left(\frac{x}{F \mathrm{e}}\right) \text { sample }}{\left(\frac{X}{F \mathrm{e}}\right) \text { background }}
$$

The average continental crustal was used as the background metal values. Table 2 shows the classification of EF values to determine the degree of metal contamination [14].

Table 2. The degree of metal pollution according to EF classes [14]

\begin{tabular}{ll}
\hline EF value & Designation of sediment quality \\
\hline$<1$ & No enrichment \\
$1-3$ & Minor enrichment \\
$3-5$ & Moderate enrichment \\
$5-10$ & Moderately severe enrichment \\
$10-25$ & Severe enrichment \\
$25-50$ & Very severe enrichment \\
$>50$ & Extremely severe enrichment \\
\hline
\end{tabular}

The PLI was calculated in order to interpret the mutual effect of different studied sediments. The PLI was determined by calculating the CF of each metal. The CF is the concentration of metal divided by the background value of this metal. The background values used here were from shallow water marine sediments [15]. The value of CF can be used to identify the contamination of an individual metal in a basin. According to previous study [16], CF can be classified into four groups: $\mathrm{CF}<1$ : low contamination factor; $1<\mathrm{CF}<3$ : moderate contamination factor; $3<\mathrm{CF}<6$ : considerable contamination factor; $\mathrm{CF}>6$ : very high contamination factor.

A PLI value that is greater than one indicates that an area is polluted, whereas no pollution or only background levels of pollutants are present if the PLI value is less than one [17,18]. The PLI can be used to identify whether the study area is collectively polluted or non-polluted by metals, where the highest PLI indicates the highest contamination. The PLI is calculated according to the following equation [15]:

$$
P L I=\sqrt[n]{C f^{m 1} \times C f^{m 2} \times \ldots \ldots \ldots . . . f^{m n}}
$$

\section{Results and discussion}

Figure 2 and 3 illustrate the water parameters distributions at Raz Al-Ardh and the Yacht Club marinas, respectively. The $\mathrm{pH}$ values were slightly higher at the Yacht Club marina when compared to Raz Al-Ardh, while the minimum $\mathrm{pH}$ value was almost similar at both locations. The $\mathrm{pH}$ values recorded at both marinas indicate slightly alkaline waters, which affect the solubility of metals.

In an earlier study at Kuwait Bay and the southern waters of Kuwait [19], it was observed that the horizontal distribution of $\mathrm{pH}$ exhibited an increasing trend at all southern stations in Kuwait Bay, compared to the northern stations. However, the difference in $\mathrm{pH}$ is not observed to be significant. In the present study, the $\mathrm{pH}$ variation was in the range of 8.55 to 8.63 .

The DO levels in the waters of the Yacht Club marina were higher when compared to the Ras Al-Ardh marina. The average surface DO of the Ras Al-Ardh marina was observed to be in the range of $7.05 \mathrm{mg} / \mathrm{l}(\mathrm{ppm})$ while the surface DO of the Yacht Club marina was recorded to be $7.69 \mathrm{mg} / \mathrm{l}(\mathrm{ppm})$. Meanwhile, previous study observed the concentration of DO ranging between 8.9 to $6.6 \mathrm{mg} / \mathrm{l}$ at Kuwait Bay [19]. 

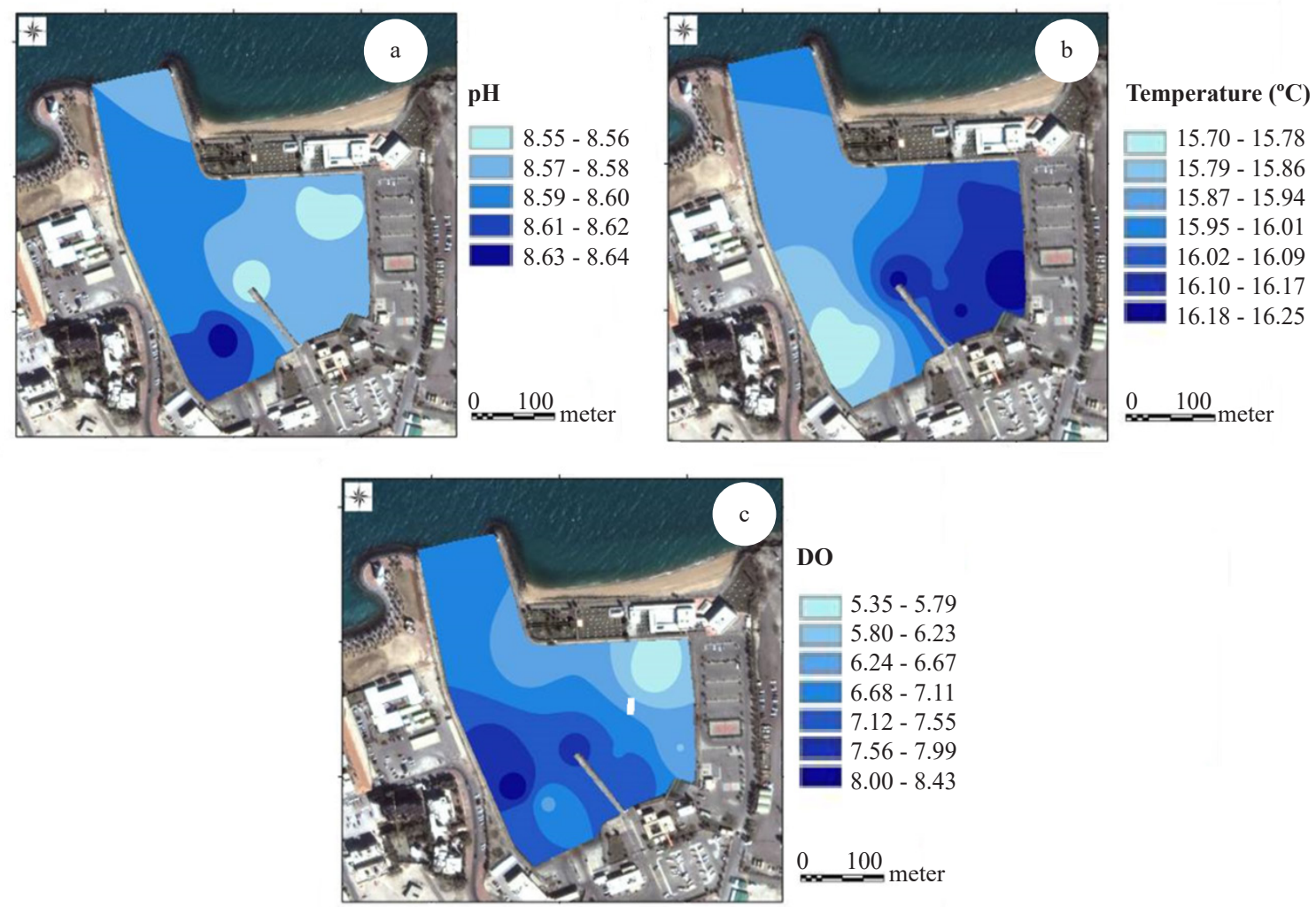

Figure 2. Distributions of (a) pH, (b) temperature, and (c) dissolved oxygen at Ras Al-Ardh marina
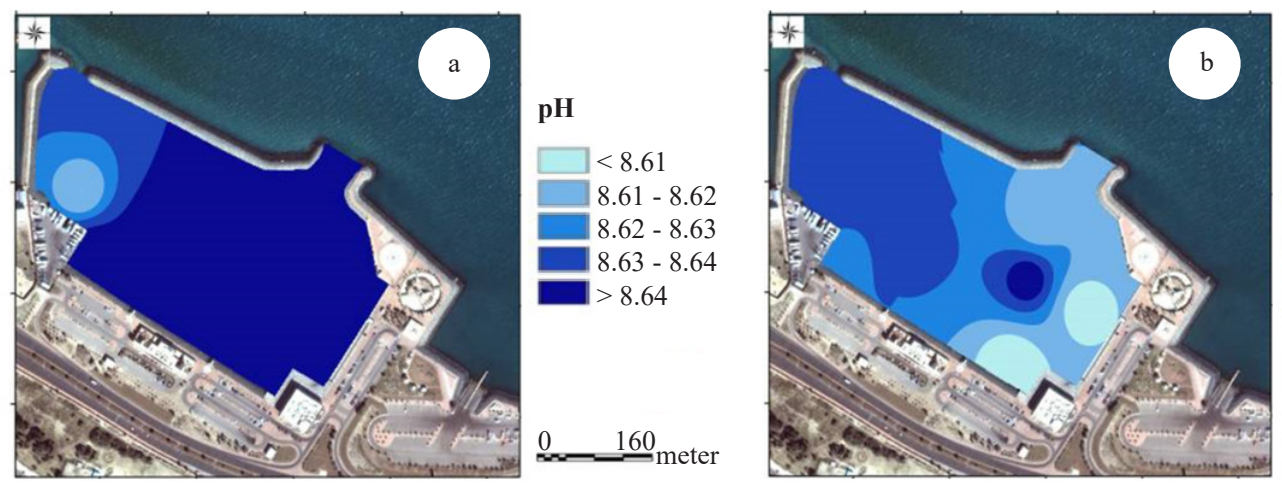

Temperature $\left({ }^{\circ} \mathrm{C}\right)$

$\square 17.52-17.63$

$17.64-17.74$

$17.75-17.86$

$17.87-17.97$

17.98 - 18.85

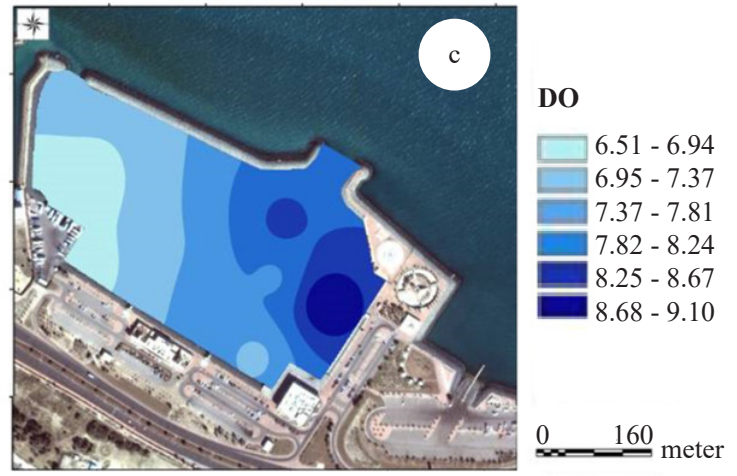

Figure 3. Distributions of (a) $\mathrm{pH}$, (b) temperature, and (c) dissolved oxygen at Yacht Club marina 
Table 3 represents a summary of the metal contents, TOC and grain size parameters (mean grain size and sorting) for both Yacht Club and Ras Al-Ardh marinas. Most of the sediments collected from the two marinas are of the grain size in the range of silt/mud (Figure 4 and 5). The mean sediment grain size varied from 0.9 to $7.83 \phi$ and 2.2 to $7.36 \phi$ for the Ras Al-Ardh and Yacht Club marinas, respectively.

Table 3. Trace metal concentrations, TOC, and average grain size and sorting for Yacht Club and Ras Al-Ardh marinas

\begin{tabular}{|c|c|c|c|c|c|}
\hline \multicolumn{2}{|c|}{ Metal/Parameter } & \multicolumn{2}{|c|}{ Yacht Club Marina } & \multicolumn{2}{|c|}{ Ras Al-Ardh Marina } \\
\hline & & $\begin{array}{l}\text { Average } \pm \text { Std. } \\
\text { Deviation }\end{array}$ & Max - Min & $\begin{array}{l}\text { Average } \pm \text { Std. } \\
\text { Deviation }\end{array}$ & Max-Min \\
\hline \multirow[t]{3}{*}{$\mathrm{Fe}(\mathrm{ppm})$} & $\mathrm{T}$ & $436.44 \pm 380.34$ & $1223.26-110.00$ & $6375.67 \pm 2584.60$ & $8547.67-456.24$ \\
\hline & $\mathrm{L}$ & $17.77 \pm 12.18$ & $40.55-6.06$ & $104.54 \pm 34.05$ & $158.00-41.06$ \\
\hline & $\mathrm{L} / \mathrm{T} \%$ & $6.43 \pm 4.89$ & $13.54-0.71$ & $4.33 \pm 9.57$ & $34.63-0.50$ \\
\hline \multirow[t]{3}{*}{$\mathrm{Ni}(\mathrm{ppm})$} & $\mathrm{T}$ & $66.53 \pm 25.61$ & $121.87-43.50$ & $109.76 \pm 35.59$ & $137.80-20.53$ \\
\hline & $\mathrm{L}$ & $1.49 \pm 0.2214$ & $1.71-1.08$ & $1.54 \pm 0.14$ & $1.72-1.24$ \\
\hline & $\mathrm{L} / \mathrm{T} \%$ & $2.42 \pm 0.61$ & $3.36-1.34$ & $1.85 \pm 1.39$ & $6.03-1.05$ \\
\hline \multirow[t]{3}{*}{$\mathrm{Pb}(\mathrm{ppm})$} & $\mathrm{T}$ & $42.35 \pm 16.02$ & $68.17-19.36$ & $17.85 \pm 11.13$ & $36.29-1.29$ \\
\hline & $\mathrm{L}$ & $3.03 \pm 0.73$ & $4.49-2.40$ & $2.44 \pm 0.47$ & $3.63-1.93$ \\
\hline & $\mathrm{L} / \mathrm{T} \%$ & $7.87 \pm 2.72$ & $12.73-4.52$ & $35.82 \pm 49.87$ & $171.43-7.04$ \\
\hline \multirow[t]{3}{*}{$\mathrm{Cu}(\mathrm{ppm})$} & $\mathrm{T}$ & $56.77 \pm 37.05$ & $127.68-13.48$ & $38.39 \pm 16.55$ & $65.20-5.90$ \\
\hline & $\mathrm{L}$ & $13.61 \pm 7.89$ & $24.41-0.79$ & $1.26 \pm 0.50$ & $2.35-0.46$ \\
\hline & $\mathrm{L} / \mathrm{T} \%$ & $26.96 \pm 14.42$ & $49.32-2.84$ & $4.10 \pm 3.28$ & $14.24-1.67$ \\
\hline \multicolumn{2}{|c|}{ TOC (\%) } & $2.74 \pm 0.88$ & $3.92-1.70$ & $2.55 \pm 1.21$ & $3.95-0.43$ \\
\hline \multicolumn{2}{|c|}{ Mean grain size (phi) } & $5.41 \pm 2.05$ & $7.36-2.20$ & $6.78 \pm 2.06$ & $7.83-0.90$ \\
\hline \multicolumn{2}{|c|}{ Sorting (phi) } & $2.62 \pm 1.19$ & $4.19-1.17$ & $1.38 \pm 0.60$ & $2.94-0.83$ \\
\hline
\end{tabular}

$\mathrm{T}=$ total, $\mathrm{L}=$ leached
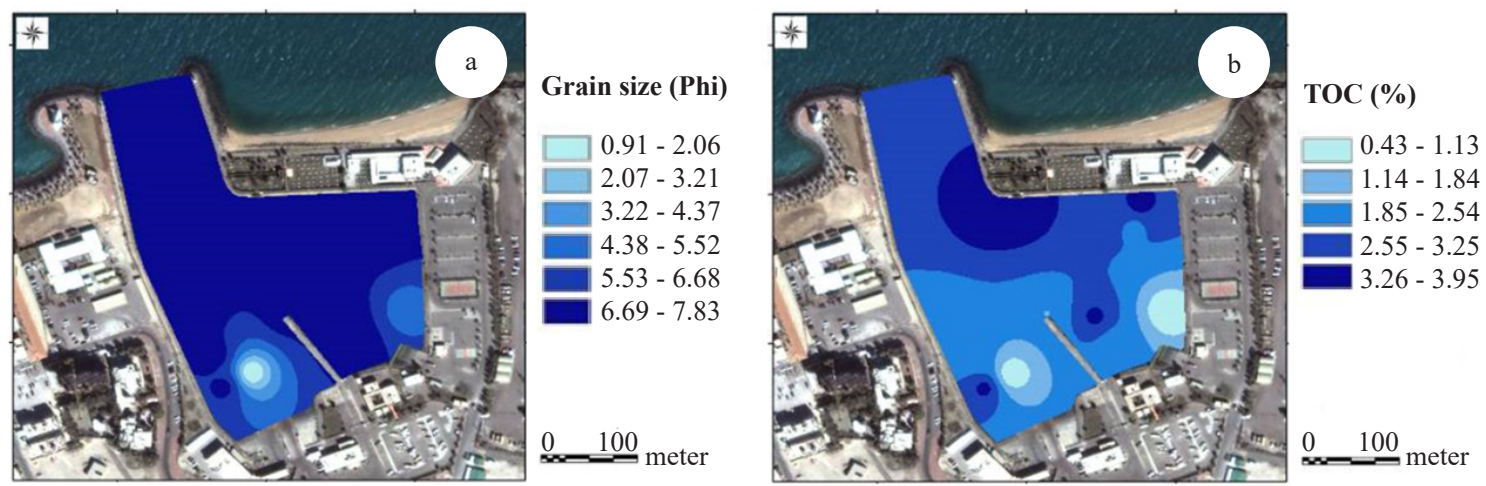

Figure 4. Grain size and TOC distributions of Ras Al-Ardh marina

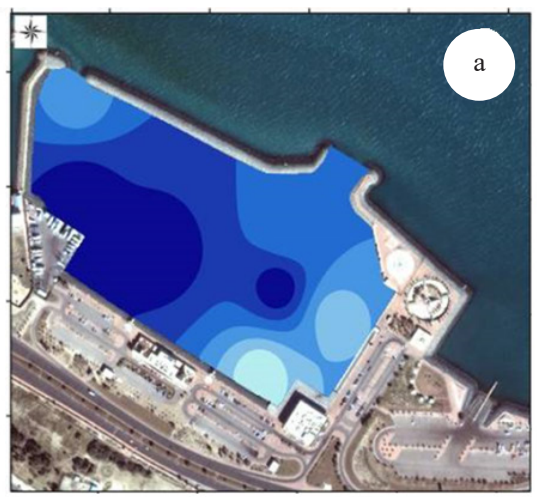

Grain size (Phi)

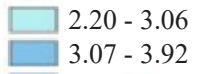

$3.92-4.78$

$4.79-5.64$

$5.65-6.50$

$6.51-7.00$
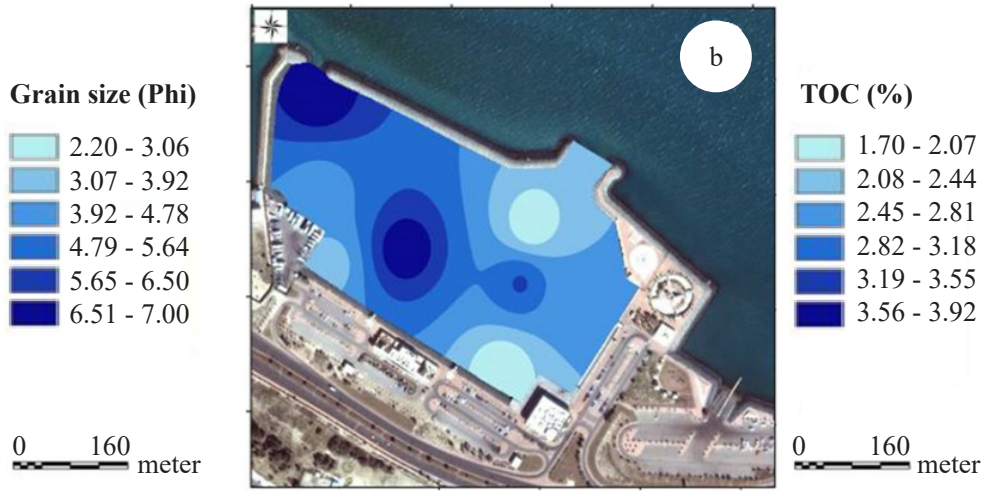

Figure 5. Grain size and TOC distributions of Yacht Club marina 
Total organic content is an indicator of marine pollution, as well as the affinity of sediments in absorbing or adsorbing toxic pollutants. The TOC concentration in the Yacht Club marina $(2.74 \pm 0.88 \%)$ was observed to be higher

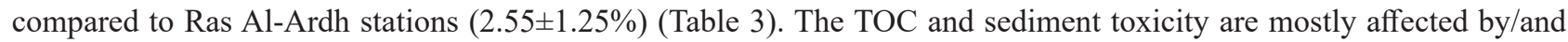
related to the grain size. At both marinas, the minimum TOC coincided with the lowest mean grain size of the sediment. This is also evident from the present study, as it can be seen that the lowest TOC and low mean grain size were observed at the same location. A wide range of variation of TOC in Kuwait's southern coastal areas was reported in an earlier study [19], where the TOC varied from 0.927 to $3.605 \%$. Generally, sediment with a finer grain size shows a higher TOC concentration.

The trace metal concentration was analyzed at the two marinas to understand the extent of pollution with respect to various activities and the degree of stress in the area caused by modern development and recreational facilities. At Ras Al-Ardh stations, the concentration of Fe and Ni (total and leached) exhibited a higher concentration compared to the Yacht Club marina (Figure 6). Ras Al-Ardh sediments exhibited a remarkable increase in Fe content (16 times higher) than those of the Yacht Club marina. At Ras Al-Ardh, the minimum concentration of total Fe coincides with the maximum concentration of leached Fe.

The concentration of $\mathrm{Ni}$ almost doubled at the Ras Al-Ardh station compared to the Yacht Club. The trace metal analysis revealed that metals such as $\mathrm{Fe}$ (leached), and total $\mathrm{Ni}$ and $\mathrm{Cu}$ were exhibiting similar trends in variation with TOC. The leached concentrations of $\mathrm{Pb}$ and $\mathrm{Cu}$ were found to be higher at the Yacht Club marina compared to the Ras Al-Ardh station (Table 3).

As per the International Atomic Energy Agency (IAEA) report [20], the $\mathrm{Cu}$ concentration ranges from 1.9 to $24 \mathrm{ppm}$, while the $\mathrm{Ni}$ and $\mathrm{Pb}$ concentrations range between 6.7 to $121 \mathrm{ppm}$ and 3.7 to $14 \mathrm{ppm}$, respectively. At six stations in the Ras Al-Ardh marina, the concentration of $\mathrm{Ni}$ was in the range of 2 to $16.8 \mathrm{ppm}$, which is higher than the maximum concentration value as reported by the IAEA. $\mathrm{Cu}$ concentration also showed an elevated value (8.7 to 41.6 $\mathrm{ppm}$ ) at Ras Al-Ardh than that of the IAEA's reported value. Meanwhile, the concentration of $\mathrm{Pb}$ increased from 4.45 to 22.3 ppm at Ras Al-Ardh.

For the Yacht Club marina, the concentration of total $\mathrm{Ni}$ is within the range of the IAEA's reported value for Kuwait (Table 3, Figure 7). The concentration of $\mathrm{Pb}$ in this marina showed a remarkably higher value compared to the IAEA's reported concentration. The concentration of $\mathrm{Cu}$ also exhibited enhanced concentration at one of the stations in this marina (the increment was in the range of 11 to $104 \mathrm{ppm}$ ). The concentration of Fe was not reported by the IAEA to be compared with the present result.

In general, it is evident that although the oceanographic conditions of the two marinas are under similar influence, the sediment toxicity at both marinas exhibit entirely different characteristics. The sediments of the Ras Al-Ardh marina were contaminated with a high concentration of $\mathrm{Fe}$ and $\mathrm{Ni}$, whereas the sediments of the Yacht Club marina were polluted with a medium concentration of $\mathrm{Cu}$ and $\mathrm{Pb}$.

The average values of the $\mathrm{L} / \mathrm{T} \%$ of the studied metals at Ras Al-Ardh marina decreased in the order of $\mathrm{Pb}>\mathrm{Cu}>$ $\mathrm{Fe}>\mathrm{Ni}$, while those estimated at the Yacht Club marina were $\mathrm{Cu}>\mathrm{Pb}>\mathrm{Fe}>\mathrm{Ni}$.

Figure 8 represents the $\mathrm{CF}$ and EF for Ras Al-Ardh marina. The values of the EF indicated that the sediments in this marina ranged from "no enrichment" to "minor enrichment". This means that the sediments were less contaminated with $\mathrm{Cu}$ relative to $\mathrm{Pb}$ and $\mathrm{Ni}$. The same results were obtained for $\mathrm{CF}$, where the sediments ranged from "low contamination" to "moderate contamination" with few locations of considerable contamination.

Figure 9 represents the CF and EF for the Yacht Club marina. The values of the EF indicated that the sediments in this marina were classified as "no enrichment", "minor enrichment" and "moderate enrichment". In fact, the sediments were less contaminated with $\mathrm{Cu}$ relative to $\mathrm{Pb}$ and $\mathrm{Ni}$. For the $\mathrm{CF}$, the sediments ranged from "low contamination" to "moderate contamination", with only one location of considerable contamination of Ni. 

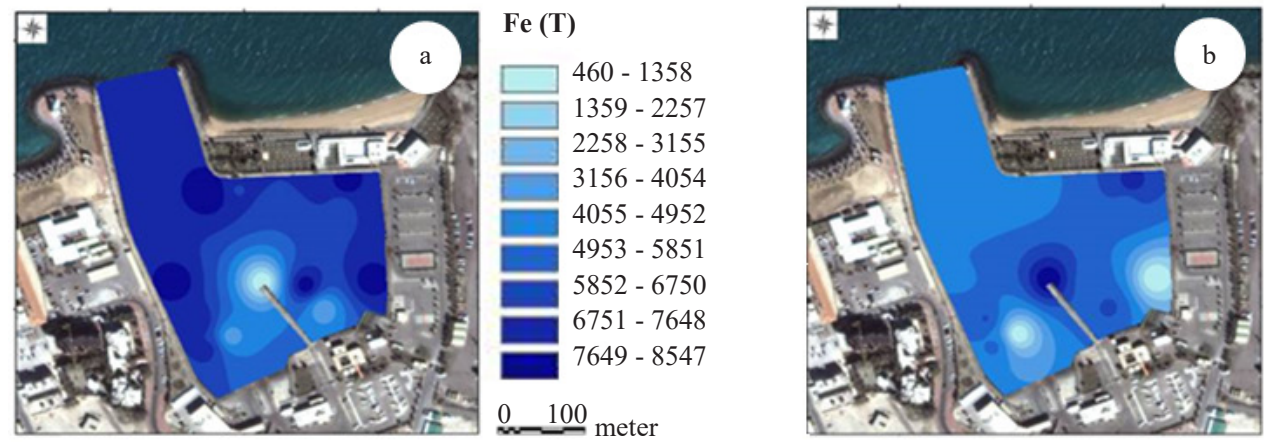

Fe (L)

$\square 41.09-54.07$

$\square 54.08-67.06$

ए $67.07-80.05$

$80.06-93.03$

— $93.04-105.02$

$105.03-119.61$

$119.62-132.00$

$132.01-144.98$

$144.99-157.97$

$0 \quad 100$ meter
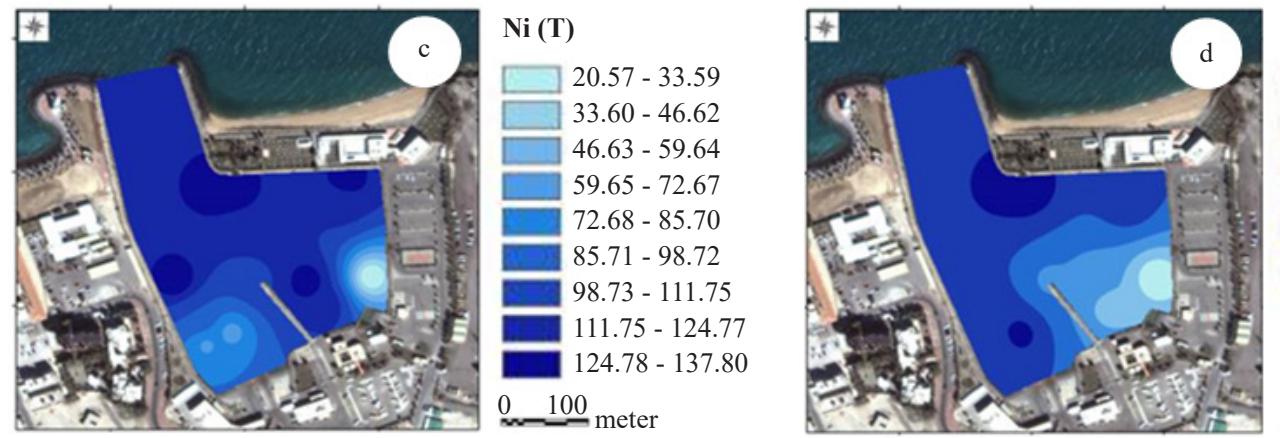

Ni (L)

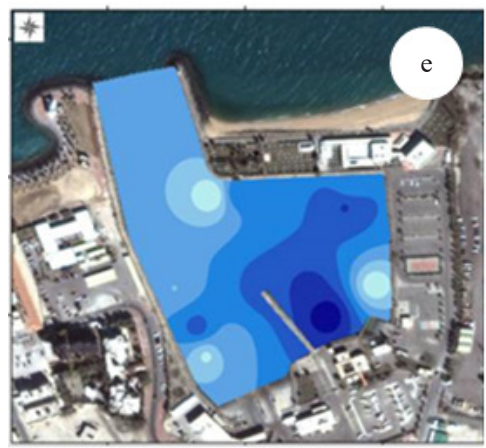

$\mathrm{Pb}$ (T)
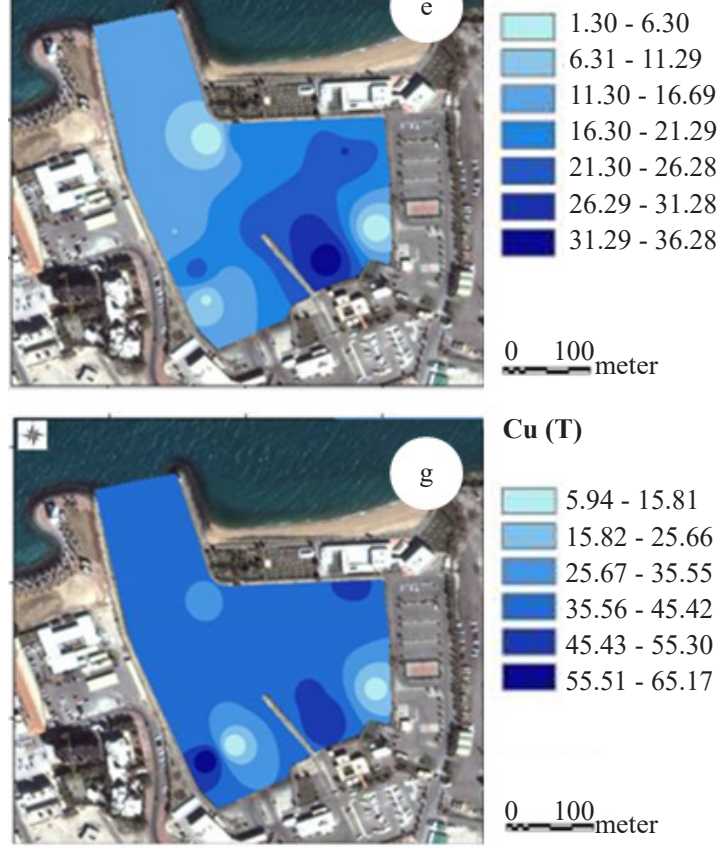

$\overbrace{}^{0 \quad 100}$ meter

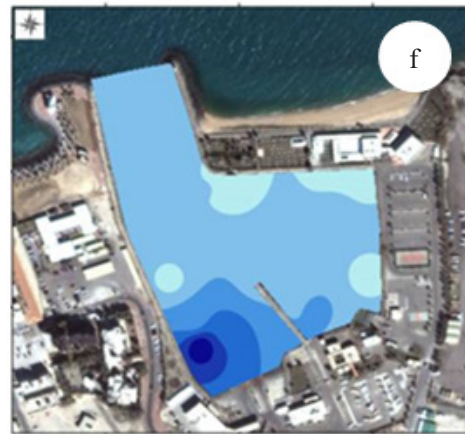

요 meter
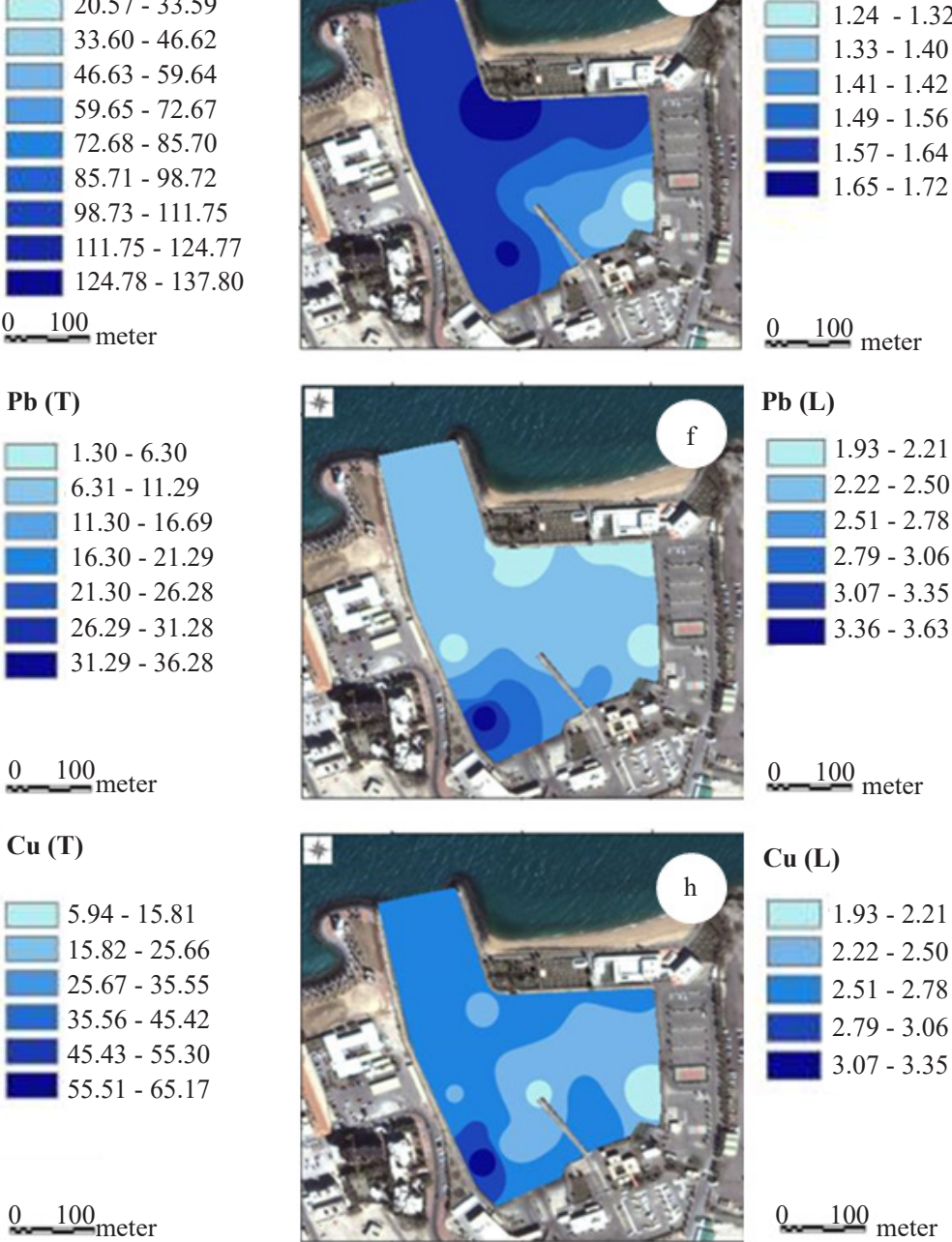

$\mathrm{Cu}(\mathrm{L})$

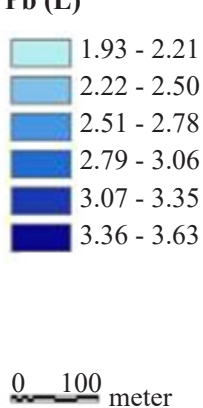

Figure 6. Distributions of total (T) and leached (L) (a, b) Fe, (c, d) Ni, (e, f) Pb, and (g, h) Cu at Ras Al-Ardh marina 

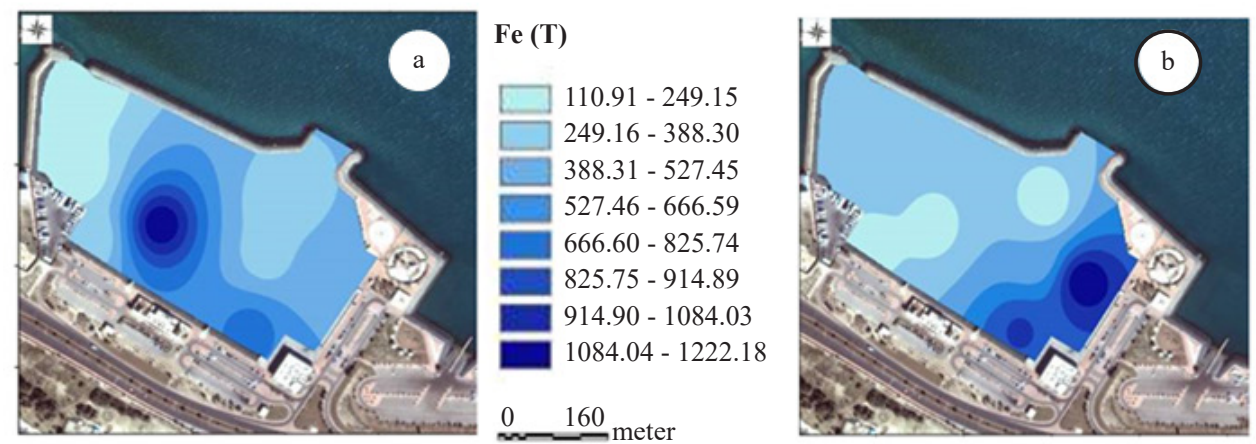

$\mathrm{Fe}(\mathrm{L})$
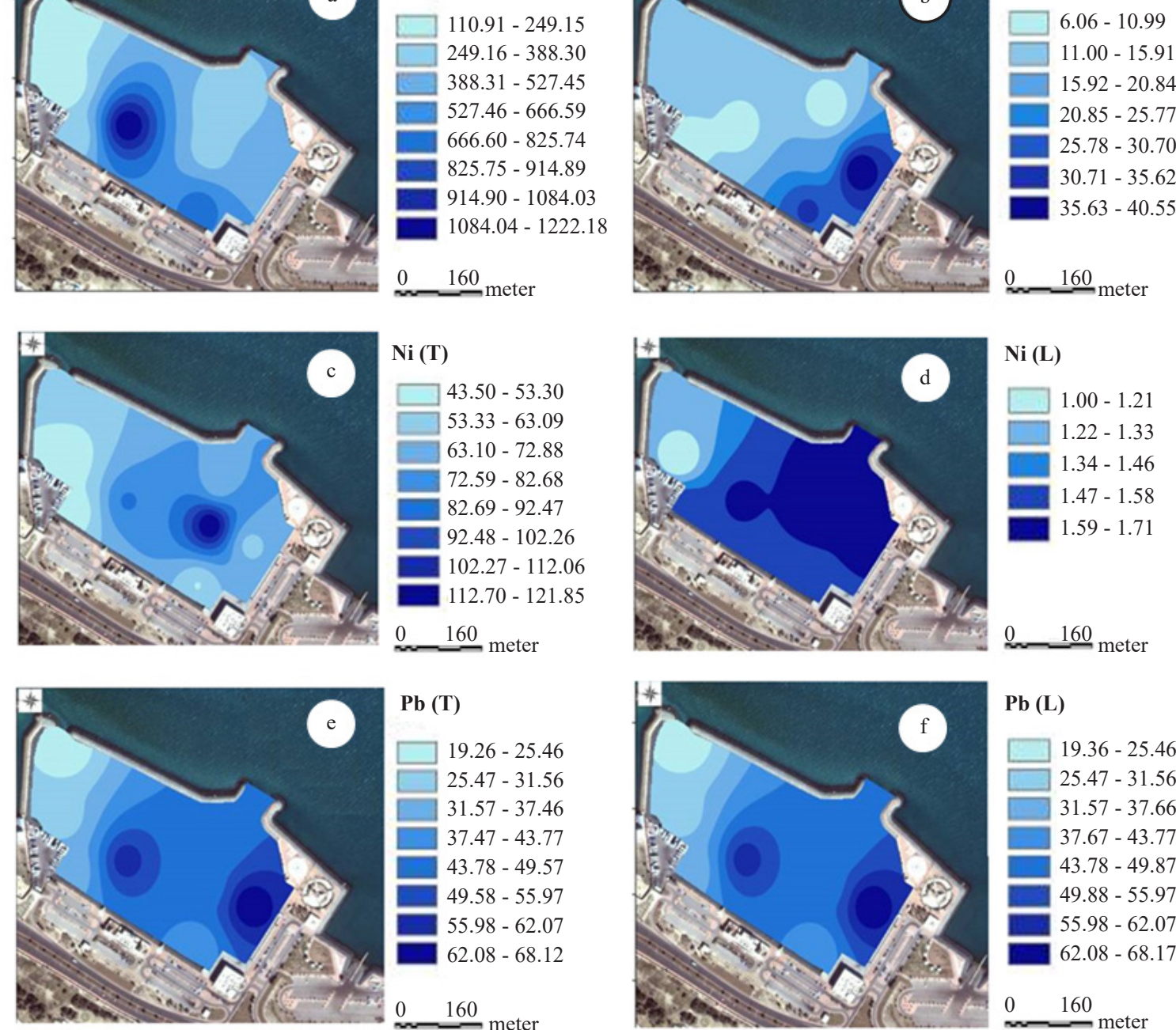

$\mathrm{Pb}(\mathbf{L})$
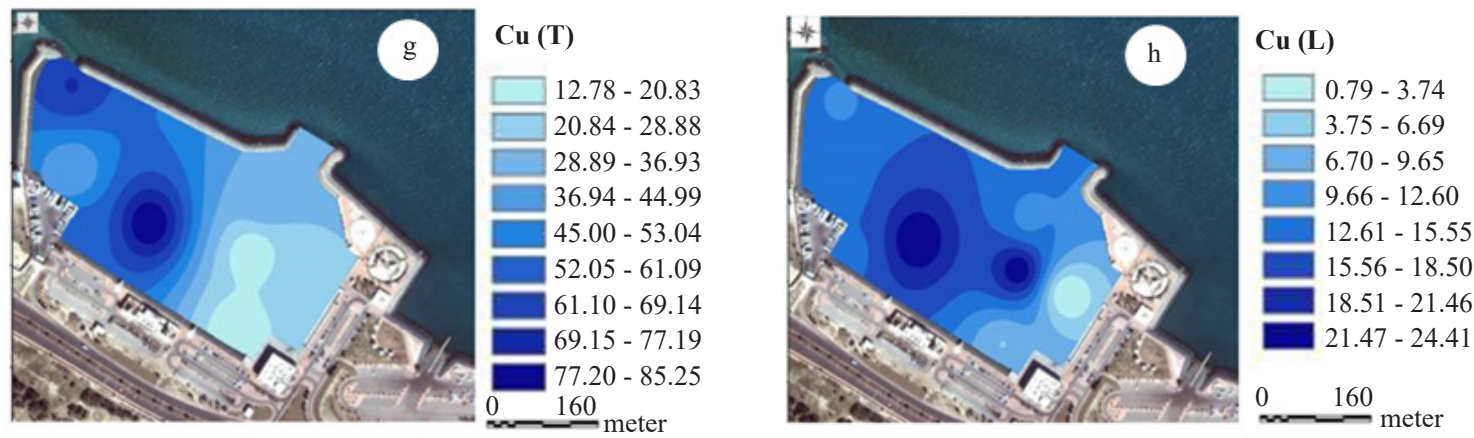

Figure 7. Distributions of total (T) and leached (L) (a, b) Fe, (c, d) Ni, (e, f) Pb, and (g, h) Cu at Yacht Club marina 

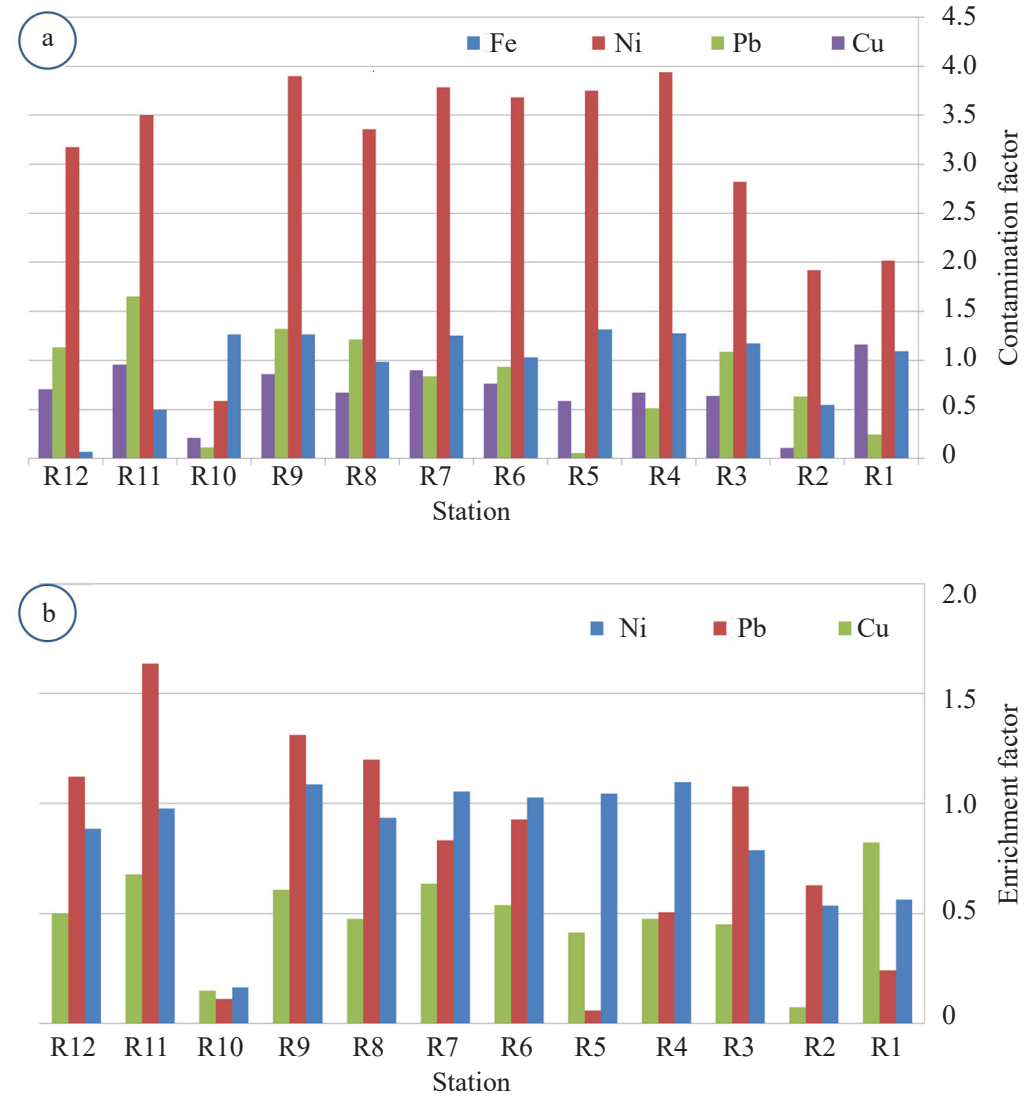

Figure 8. Contamination and enrichment factors of Ras Al-Ardh marina
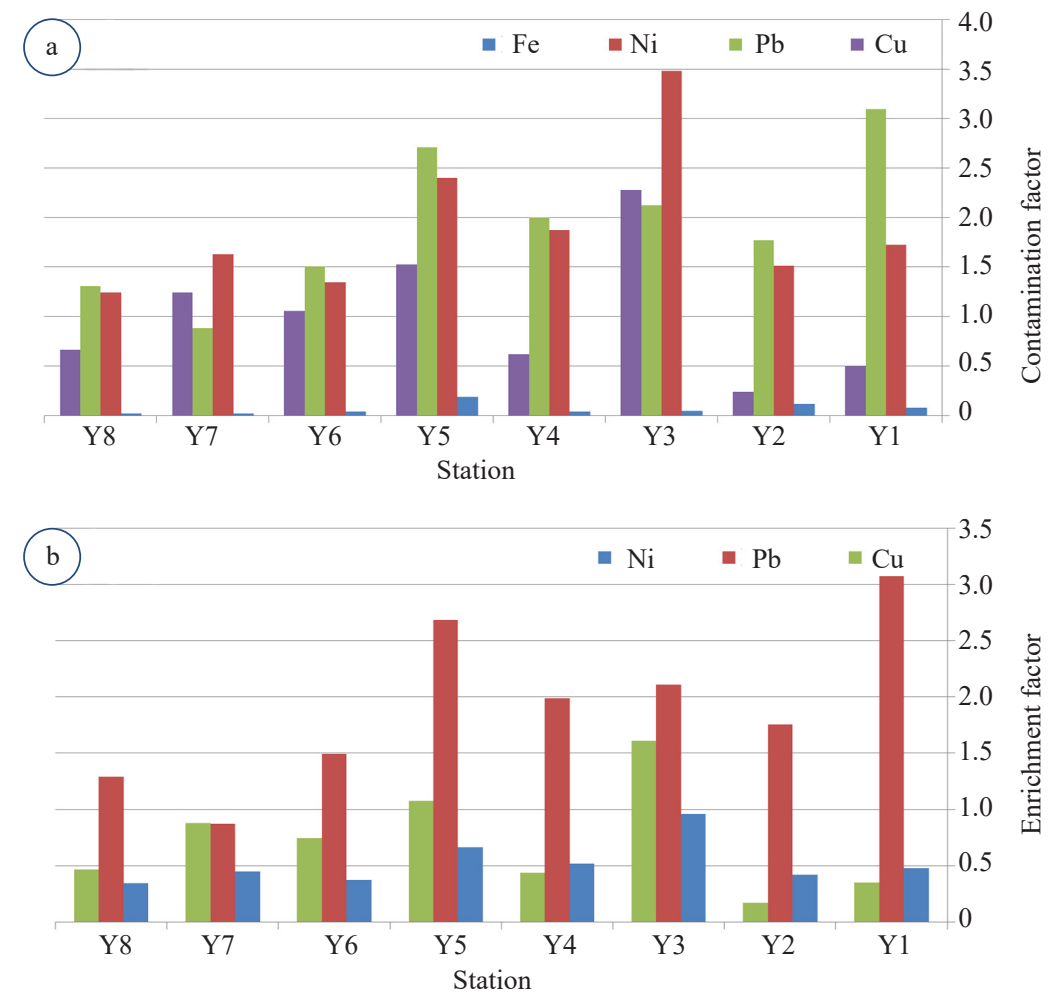

Figure 9. Contamination and enrichment factors of Yacht Club marina 
In order to interpret the mutual effect of the heavy metal levels in the sediments of both the marinas, PLI was estimated. When the PLI values were compared to the contamination levels as reported in previous research [21], the sediments at the Yacht Club marina fell into Class 1 of metal contamination type and were classified as "uncontaminated" to "moderately contaminated". The PLI determined at Ras Al-Ardh marina indicated that the sediment contamination fell between Class 1 and Class 2. Metals are concentrated in the enclosed region (eastern corner) of the Ras Al-Ardh marina due to the minimum movement of sediments towards the offshore (Figure 10). Figure 11 illustrates the relation between the PLI and TOC of both marinas. It is obvious that PLI was interrelated with TOC, where the PLI values increased with increasing TOC concentrations.
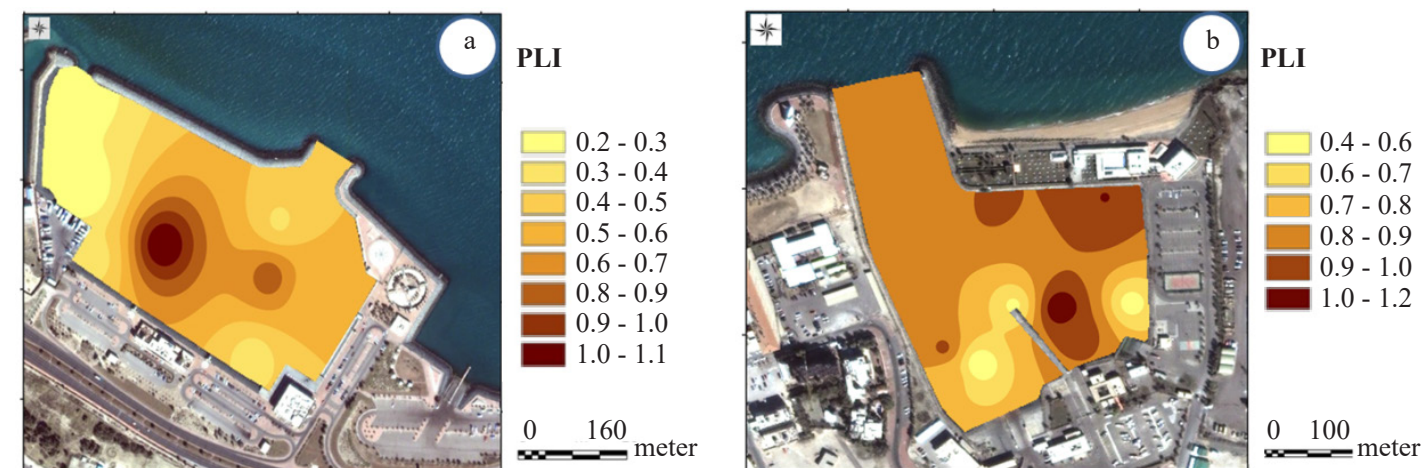

Figure 10. Distributions of PLI at (a) Yacht Club and (b) Ras Al-Ardh marinas

a)

$\longrightarrow$ TOC $(\%) \quad \longrightarrow$ PLI

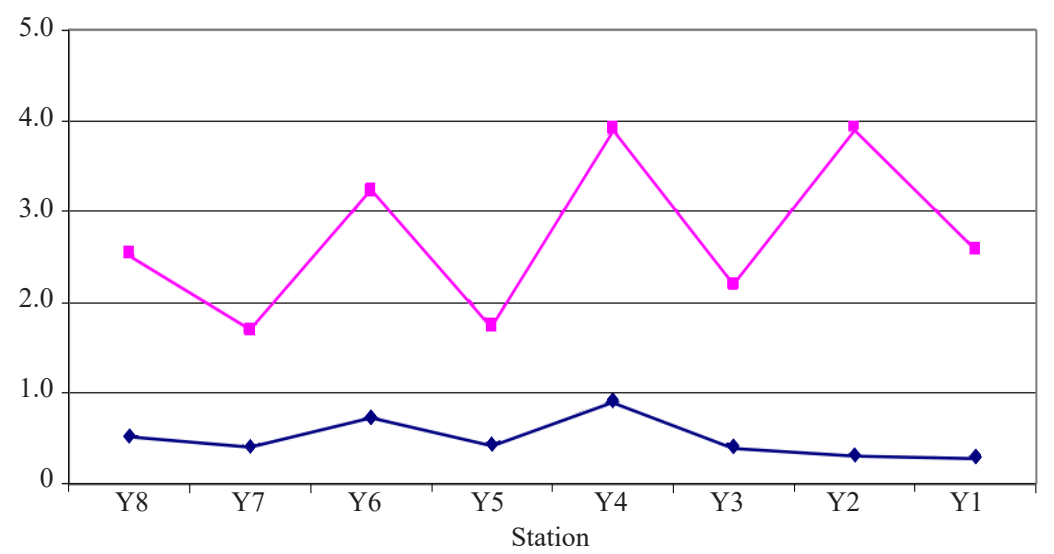

b)

$\longrightarrow$ TOC $(\%) \quad \longrightarrow$ PLI

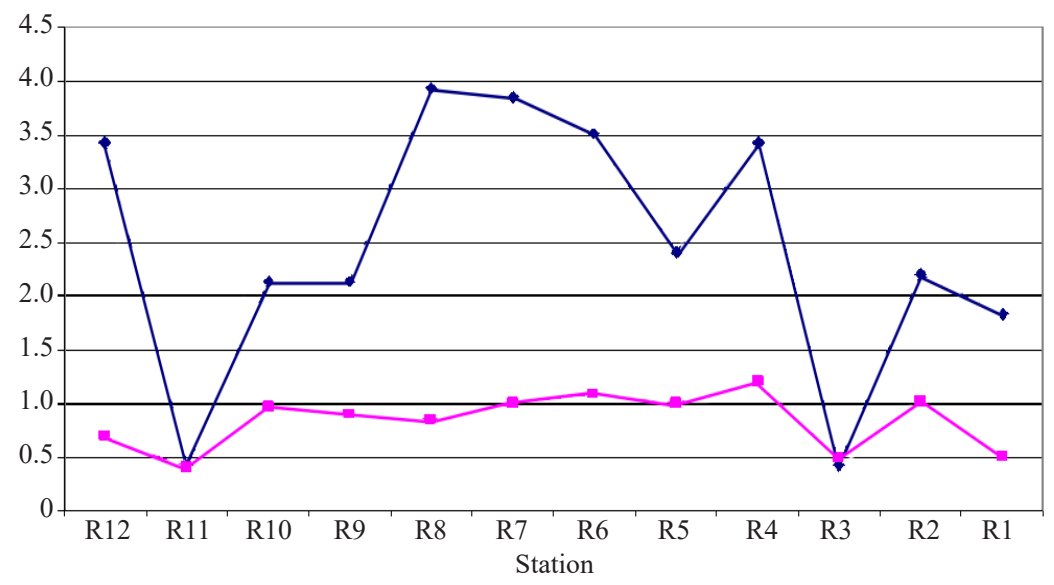

Figure 11. Relation between PLI and TOC for (a) Yacht Club and (b) Ras Al-Ardh marinas 


\section{Conclusion}

In Kuwait, the expansion of tourism, industrial activities, and increasing recreational requirements near the coastal areas are causing tremendous changes to the marine water and sediment quality. This causes severe stress to marine organisms, including fish, and poses a threat to marine resources. Recently, Kuwait's coastal area has seen an increase in the number of marinas (from small to large size), which primarily involve social activities and leisure centers with health clinics.

The trace metal analysis revealed that metals such as $\mathrm{Fe}$ (leached), and total $\mathrm{Ni}$ and $\mathrm{Cu}$ were exhibiting similar trends in variation when compared to the TOC variation in Ras Al-Ardh. The larger the organic content, the more oxygen is consumed. A high organic content means an increase in the growth of microorganisms, which contributes to the depletion of oxygen supplies. The source of this organic material could be from the wastewater released by the wastewater treatment plant into the gulf. Industrial waste effluent may contain carbon-containing compounds with various toxicity levels. Both situations may create unfavorable conditions for aquatic life, including the depletion of oxygen and the presence of toxic substances.

On the other hand, at Ras Al-Ardh stations, the concentration of total and leached Fe and Ni exhibited a higher concentration compared to that of the Yacht Club marina. Ras Al-Ardh sediments exhibited a remarkable increase in Fe content (16 times higher) than those of the Yacht Club marina. At Ras Al-Ardh, the minimum concentration of Fe (total) coincided with the maximum concentration of Fe (leached).

Based on the highly elevated concentrations of trace metals at Ras Al-Ardh marina, it is concluded that the aquatic life in the underlying water is under stress and needs to be considered for impact studies and measures to remediate it. This marina accommodates many boats and a dockyard (boat workshop), and it discharges dockyard waste, oil and other non-point discharges. An increase in marine traffic due to repair and recreational needs may also contribute to this enhanced concentration of trace metals. Likewise, the Yacht Club marina sediment also exhibited high concentrations of $\mathrm{Pb}$ and moderate concentrations of $\mathrm{Cu}$. Hence, impact studies should be considered for this marina and measures should be taken to remediate the risk of higher pollution of $\mathrm{Pb}$ and $\mathrm{Cu}$.

\section{References}

[1] Devlin MJ, Lyons BP, Bacon J, Edmonds N, Tracey D, Al Zaidan AS, Al Ajmi F, Al-Wazzan ZA, Al-Hussain MM, Al Khaled H, Le Quesne WJF. Principles to enable comprehensive national marine ecosystem status assessments from disparate data: The state of the marine environment in Kuwait. Estuarine, Coastal and Shelf Science. 2019; 230: 106407. Available from: doi: 10.1016/j.ecss.2019.106407.

[2] Baby S, El-Sammak A. Application of RIAM for Evaluation of potential environmental impacts for shore-zone development. In: Proceedings of the International Conference on Chemistry and Chemical Engineering 2010, 1 Aug 2010, Kyota, Japan. New Jersey: IEEE; 2010. p. 444-450.

[3] Khan NY. Human and Physical Geography (Chapter 1). In: Khan NY, Munawar M, Price AR. (eds.) The Gulf Ecosystem Health and Sustainability. Leiden, The Netherlands: Backhuys; 2002.

[4] Waheshi YA, El-Gammal MI, Ibrahim MS, Okbah MA. Distribution and assessment of heavy metal levels using geoaccumulation index and pollution load index in Lake Edku sediments, Egypt. Egypt IJEMA. 2017; 5(1): 1-8. Available from: doi: 10.11648/j.ijema.20170501.11.

[5] El-Magd SA, Taha TH, Pienaar HH, Breil P, Amer RA, Namour P. Assessing heavy metal pollution hazard in sediments of Lake Mariout, Egypt. Journal of African Earth Sciences. 2021; 176: 104116. Available from: doi: 10.1016/j.jafrearsci.2021.104116.

[6] Ben Amor R, Yahyaoui A, Abidi M, Chouba L, Gueddari M. Bioavailability and assessment of metal contamination in surface sediments of Rades-Hamam lif coast, around Meliane River (Gulf of Tunis, Tunisia, Mediterranean Sea). Journal of Chemistry. 2019; 2019: 1-11. Available from: doi: 10.1155/2019/4284987.

[7] Bu-Olayan AH, Subrahmanyam MN, Al-Sarawi M, Thomas BV. Effects of the Gulf War oil spill in relation to trace metals in water, particulate matter, and PAHs from the Kuwait Coast. Environment International. 1998; 24(7): 789797.

[8] Bu-Olayan AH, Al-Hassan R, Thomas BV, Subrahmanyam MN. Impact of trace metals and nutrients levels on phytoplankton from the Kuwait Coast. Environment International. 2001; 26(4): 199-203. 
[9] Sabarathinam C, Bhandary H, Al-Khalid A. A geochemical analogy between the metal sources in Kuwait Bay and territorial sea water of Kuwait. Environmental monitoring and assessment. 2019; 191(3): 1-9. Available from: doi: 10.1007/s10661-019-7219-4.

[10] Loring DH, Rantala RT. Manual for the geochemical analyses of marine sediments and suspended particulate matter. Earth-science reviews. 1992; 32(4): 235-83. Available from: doi: 10.1016/0012-8252(92)90001-A.

[11] El-Sammak A. Heavy metal pollution in bottom sediment, Dubai, United Arab Emirates. Bulletin of environmental contamination and toxicology. 2001; 67(2): 295-302.

[12] Regional Organization for the Protection of the Marine Environment, Kuwait (ROPME). Manual of Oceanographic Observation and Pollutant Analyses Methods. ROPME. 2010. p. 1-54

[13] Sharifuzzaman SM, Rahman H, Ashekuzzaman SM, Islam MM, Chowdhury SR, Hossain MS. Heavy metals accumulation in coastal sediments. In: Hasegawa H, Rahman I, Rahman M. (eds.) Environmental remediation technologies for metal-contaminated soils. Tokyo: Springer; 2016. p.21-42. Available from: doi: 10.1007/978-4431-55759-3_2

[14] Taylor SR. A $\bar{b}$ undance of chemical elements in the continental crust: a new table. Geochimica et cosmochimica acta. 1964; 28(8): 1273-1285. Available from: doi: 10.1016/0016-7037(64)90129-2.

[15] Salomons W, Förstner U. Metals in the Hydrocycle. Berlin: Springer Science \& Business Media; 2012.

[16] Hakanson L. An ecological risk index for aquatic pollution control. A sedimentological approach. Water research. 1980; 14(8): 975-1001.

[17] Chakravarty M, Patgiri AD. Metal pollution assessment in sediments of the Dikrong River, NE India. Journal of Human Ecology. 2009; 27(1): 63-67.

[18] Mashiatullah A, Chaudhary MZ, Ahmad N, Javed T, Ghaffar A. Metal pollution and ecological risk assessment in marine sediments of Karachi Coast, Pakistan. Environmental Monitoring and Assessment. 2013; 185(2): 15551565 .

[19] El-Sammak A, Khan NY, AlGhadban AN, Beg MU, Saeed T, Karam Q, AlShemmari H, Al. Nafissi R, Al. Bloushi A, AlMatrouk K, Al. Bahloul M, Rajagopal S, Al. Omani N. Assessment of sediment quality in Kuwait's territorial waters: Phase II Coastal area south of Raz Al-Ardh and along the northern territorial waters. Kuwait Institute for Scientific Research. Report number: 7162, 2004.

[20] International Atomic Energy Agency (IAEA). Annual Report. Vienna: IAEA, 1999.

[21] Muller G. Schwermetalle in den sediments des Rheins-Veranderungen seitt 1971. Umschau. 1979; 79: 778-783. 